\title{
SUSTAINABILITY OF CHEMICAL SOIL QUALITY IN SOUTHERN MORAVA RIVER VALLEY IN CORRELATION WITH THE FLOODING $^{1}$
}

\author{
Jelena Markovic ${ }^{2}$, Svetlana Stevovic ${ }^{3}$
}

\section{Summary}

Land as the main edaphic factor, plays a very important role in the production of various field crops, fruit and vine crops. Its role is reflected in the fertility and productivity. Soil fertility includes content available nutrients, such as individual elements, $p H$ and humus. The study of soil quality leads to conclusions about what the land is suitable for cultivation of what kind of culture. This paper presents the results of investigation of changes in soil quality in the South Morava river valley, in correlation with the floods. Different results of $\mathrm{pH}$, humus, nitrogen, phosphorus and potassium, are obtaind in the function of time, within the research conducted. Experiment was implemented two years ago, immediately after the flood and six months after the floods, which occurred in May 2014 in the region South Serbia. The methods that were used for the analysis of the soil are: colorimetric, photometric, potentiometric and spectrophotometry. Results show a high degree of sustainability of quality of land intended for the cultivation of field crops. The conclusion is that the soil relatively quickly regenerate their properties after floods.

Keywords: South Morava river, soil, potassium, phosphorus, humus, flooding

JEL: $Q 17, Q 52$

\section{Introduction}

The land is diverse and represented smonitza, forest soil, podzol, and there are traces of mountain black soil.The plot is loose surface layer of the earth's crust formed as a product of the geological substrate and the participation of climatic factors (especially

1 This research was supported by the Ministry of Education, Science and Technology Development of Serbia, grant No. EE18031 and TR35030.

2 Jelena Markovic, $\mathrm{PhD}$, Colledge of Applied Professional Studies, Filipa Filipovica 20, Vranje, Serbia, Phone: +381 652040022, E-mail gogaijeka94@gmail.com.

3 Svetlana Stevovic, PhD, Full Professor University Union Nikola Tesla, Faculty for ecology and environmental protection, Cara Dusana 62-64, Belgrade, Serbia, Phone: +381638882541 , E-mail svetlanas123@gmail.com

EP 2017 (64) 4 (1425-1436) 
temperature, water, air movement and gravity) and living beings (particularly important as plant organisms and microorganisms). The land is an integral part of the ecosystem and is situated between the Earth's surface and the wall. It is divided into horizontal layers and different in their chemical, physical and biological characteristics. Quality land has approximately $50 \%$ solids and $45 \%$ to $5 \%$ of mineral and organic substances, and $25 \%$ containing water and air (Altieri, et al. 1995). Composition of land directly affects the anatomical structure of plants and their characteristics (Stevovic, 2010), (Stevovic et al., 2009). Depending on the amount of chemical elements present $\mathrm{N}$ (nitrogen), $\mathrm{P}$ (phosphorus) $\mathrm{K}$ (potassium), of humus and $\mathrm{pH}$ value depends on the quality of soil. Soil quality is reflected in its fertility, and thus the yield of the plants that grow on the same land, (Stevovic and Calic-Dragosavac, 2010), (Stevovic et al., 2013). If the soil is rich in nitrogen, then the plant will have a normal flowering, better fruiting and reduced yellowing leaves (Altieri, et al. 1995). In order to process the construction of nucleic acids, nucleoproteins and phytate performed properly, the land is required to be rich in phosphorus. However soil is generally low in phosphorus and subsequently carries phosphorous fertilizers (Altieri et al. 1995). To make the plants resist on steres and diseases it is necessary that the land is rich in potassium. Potassium is the essential for cell growth and division in plants (Stevovic et al., 2010). The lack of potassium in the soil causes a disruption in water balance, dry tops or curling of leaves and root rot. Successive changes, such as deficiencies of nutrients in the soil create problems. (Spooler, 2008). Sustainable agricultural intensification is defined as producing more output from the same area of land while reducing the negative environmental impacts and at the same time increasing contributions to natural capital and the flow of environmental services (Pretty, 2008; Royal Society, 2009; Conway, Waage, 2010; Godfray et al., 2010).

The increased amount of moisture in the soil also affects the poor quality of the soil. Flooding can have a very negative effect on land, these effects can be: sludge sedimentation, erosion of agricultural land, loss of nutrients in the soil, which affect fertility. This paper will discuss the sustainability of soil quality in the period before, immediately after the flood, and six months after the floods. This implies that take into account the influence of environmental factors, which comprise the complex factors influencing the land (Krnacova, et al., 2013).

Crop production includes production of all major field crops: wheat, corn, soybean, sunflower, rapeseed and sugar beet with the use of agro-technical measures and the use of latest machinery in agricultural production, with optimal use of chemical protection and respecting the agro deadlines. The cultivation of crops, except for the application of agro-technical measures and soil quality, plays a big role on wer as climatic factors.

\section{Materials and metods}

For this work samples of soils, were taken from the grounds of the villages located next to the South Morava river valley. These are the villages Cukovac, Zlatokop, Ribnice and Kupinince. 
Figure 1. Villages Cukovac, Zlatokop, Ribnice and Kupinince

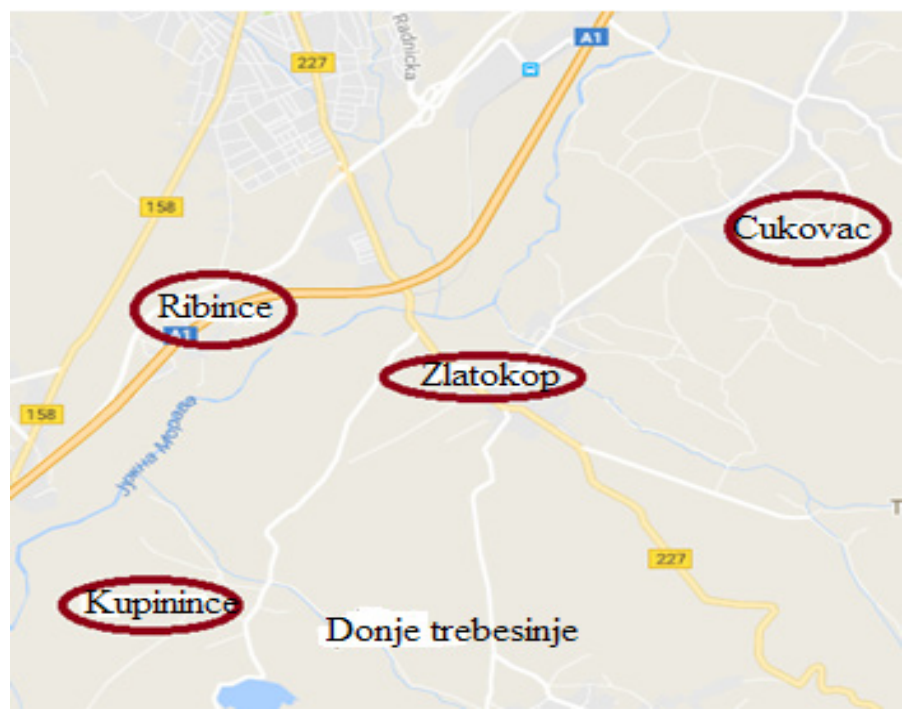

Source: Online satellite images and maps Vranje, Dubnica, Bresnica, Suvi Do, Ivankovci, Toplac, Bujkovac, Vranska Banja, Katalenac, Durinci etc.

We examined the quality of the soil on which crops are sown in the period before during and after the flood to. Tests the change of the quality of the soils. Type of soil that have been tested is vertisol and sandy soil. Resin is black, clayey soil rich in humus and belong to our fertile soil. The composition and quality of the soil impacts the yield of grown crops. Soil samples that were used for the analysis were tested in the laboratory of Agricultural advisory and extension services in Vranje.

Soil samples were taken from smaller parcels. Soil samples were taken from a depth of $15 \mathrm{~cm}$. Time sampling was after cereal and corn harvest. Colorimetric method is based on the fact that some of the elements in this case $\mathrm{K}$ and $\mathrm{P}$, when dissolved in a particular solvent, give characteristically colored solutions, or the colouration arises as a result of the reaction of the given substance and the corresponding reagent. The intensity of the resulting coloration depends on the concentration of the test substance in the solution. By measuring the intensity of the coloring, the concentration of the test element in the solution can be quantitatively determined. The task of calibration is to determine how much the content analyzed of nutrients is significant for the grown crops, as well as the significance of other properties of the soil, to what extent the availability of nutrients is important for cultivated crops. Calibration should show where are the boundaries of weakness and good level of supply of some soil with phosphorus, potassium and other nutrients, (Kovacevic, 2003.). The percentage of humus content in the soil is determined by the formula: 
Where

$$
\text { Humus }(\%)=\frac{A \cdot 0,514 \cdot 1,2 \cdot 100}{C}
$$

$\mathrm{A}$-is the amount of $0.1 \mathrm{n} \mathrm{KMnO}_{4}$ spent on carbon oxidation in humus $\mathrm{cm}^{3}$;

1.72 - coefficient for translating carbon into humus because it has been experimentally found that the content of carbon in humus is $58 \%(100: 58=1.724)$;

0.514 - coefficient indicating that each $\mathrm{cm}^{3}$ of $0,1 \mathrm{n} \mathrm{KMnO}_{4}$ oxidizes $0,514 \mathrm{~g}$ of carbon into $\mathrm{CO}_{2}$;

100 - coefficient for calculation of percentages;

$\mathrm{C}$ - is the mass of the air of dry soil taken for analysis.

$$
\text { Nitrogen }(\%)=0,05 \cdot \text { humus }
$$

Results of testing various samples of the soil are analyzed in the period from July 2013 to October 2014. The results are presented in tables 1 .

\section{Results and discussion}

The results obtained in this study indicate different soil quality. Table 1 shows the results of the quality of the land on which crops are sown in the period of 2012. The aim was to show the content of nitrogen, phosphorus, potassium and humus in the soil and what is the $\mathrm{pH}$ value of such land after harvest.

Table 1. The content of various parameters in the examined samples countries $(K, P$, humus, $\mathrm{N}$ and $\mathrm{pH}$ in \%)

\begin{tabular}{|c|c|c|c|c|c|c|}
\hline Soil sample & Soil type & $\mathbf{p H}$ & Humus, \% & $\begin{array}{c}\mathbf{N}, \\
\mathbf{\%}\end{array}$ & $\begin{array}{c}\text { P, } \\
\mathbf{\%}\end{array}$ & $\begin{array}{c}\text { K, } \\
\mathbf{\%}\end{array}$ \\
\hline \multicolumn{6}{|c|}{ Cukovac } \\
\hline 1 & Vertisol & 5.43 & 3.58 & 0.2 & 10.21 & 34 \\
\hline 2 & Vertisol & 6.02 & 2.74 & 0.17 & 15.17 & 11.22 \\
\hline 3 & sandy soil & 5.78 & 3.14 & 0.19 & 12.78 & 31.23 \\
\hline 4 & sandy soil & 6.42 & 5.28 & 0.23 & $>40$ & 21.14 \\
\hline \multicolumn{7}{|c|}{ Zlatokop } \\
\hline 5 & Vertisol & 5.71 & 9.14 & 0.42 & $>40$ & 18.79 \\
\hline 6 & Vertisol & 5.31 & 2.45 & 0.13 & 20.15 & $>40$ \\
\hline 7 & sandy soil & 4.78 & 4.85 & 0.28 & 37.76 & 15.22 \\
\hline 8 & sandy soil & 4.79 & 3.78 & 0.25 & 17.87 & 22.13 \\
\hline \multicolumn{7}{|c|}{ Ribince } \\
\hline 9 & Vertisol & 5.56 & 8.24 & 0.39 & 36.18 & 35.41 \\
\hline 10 & Vertisol & 5.06 & 5.15 & 0.24 & 19.21 & 24.31 \\
\hline 11 & sandy soil & 4.49 & 3.78 & 0.18 & 9.48 & 32.41 \\
\hline 12 & sandy soil & 5.15 & 2.40 & 0.12 & 16.26 & 10.86 \\
\hline \multicolumn{7}{|c|}{ Kupinince } \\
\hline 13 & Vertisol & 5.09 & 3.34 & 0.14 & 15,24 & 18.64 \\
\hline 14 & Vertisol & 6.75 & 9.17 & 0.46 & $>40$ & 36.52 \\
\hline
\end{tabular}




\begin{tabular}{|c|c|c|c|c|c|c|}
\hline Soil sample & Soil type & $\mathbf{p H}$ & Humus, \% & $\begin{array}{c}\mathbf{N}, \\
\mathbf{\%}\end{array}$ & $\begin{array}{c}\mathbf{P}, \\
\mathbf{\%}\end{array}$ & $\begin{array}{c}\mathbf{K}, \\
\mathbf{\%}\end{array}$ \\
\hline 15 & sandy soil & 5.45 & 3.51 & 0.17 & 16.92 & 33.12 \\
\hline 16 & sandy soil & 4.76 & 4.15 & 0.29 & 21.05 & 14.73 \\
\hline
\end{tabular}

Source: Author's calculation based on the survey data

In soil samples in which $\mathrm{K}, \mathrm{P}$, Humus, $\mathrm{N}$ and $\mathrm{pH}$ were tested before flooding, it is evident that the soil is mostly acidic because the $\mathrm{pH}$ is in the range of 4.48-6.42, except in the sample 14 where the $\mathrm{pH}$ is 6.75 and that sample the soil has a neutral reaction. Before the flood, the soil was rich in nitrogen. The percentage of nitrogen was in the range of 0.12 in the Ribnice location in the sample of 12 types of soil sandwiches, up to 0.46 in the sample number 14 at the site Kupinince type on vertisol. Percentage K variedin the range of 10.86 in the Ribnice location in the sample number 12 on the sany soil to up to 40 in the sample number 6 at the Zlatokop site on the same type of soil. Regarding P, its value was from 9.48 in sample number 11 at the Ribnice location on sandy soil, and up to $40 \%$ at the location Cukovac in sample number 4 of the same type of soil, in sample number 5 at Zlatokop and Kupininc in the sample number 14 on the vertisol. Based on the obtained results for the values of $\mathrm{K}$ and $\mathrm{P}$, it can be said that the soil is mostly of high quality phosphorus and potassium. The percentage of humus in the samples was the smallest at Zlatokop site in sample number 6 and amounted to 2.45, while the highest percentage of humus was at Kupinince site in sample number 149.17 , in both samples on vertisol.

Table 2 shows the results from the same land parcel located in the valley of the South Morava River, but immediately after the flood. that lasted 15 days, in May 2014. After the flood, it took a long time for land to dried out. The obtained results show a large deviation in terms of soil quality. From the results obtained, Table 2 (before floods) shows a lower level of nitrogen in soil samples at Ribince 0.12 for the sandy soil, at the site Kupinince 0.14 for the type of sand, at the site Cukovac 0.17 for the type of sandblast and ice cream and at Zlatokop, the percentage of nitrogen is 0.13 , which is the case with the type of resin. It can be noticed that for the type of soil, the percentage of nitrogen is lower.

Table 2. The content of various parameters in the examined samples of the country immediately after the flood

\begin{tabular}{|l|c|c|c|c|c|c|}
\hline Soil sample & Soil type & $\mathbf{p H}$ & Humus, \% & $\begin{array}{l}\mathbf{N}, \\
\mathbf{\%}\end{array}$ & $\begin{array}{c}\mathbf{P}, \\
\mathbf{\%}\end{array}$ & $\begin{array}{c}\mathbf{K}, \\
\mathbf{\%}\end{array}$ \\
\hline \multicolumn{7}{|c|}{ Cukovac } \\
\hline 1 & Vertisol & 5.18 & 2.85 & 0.19 & 9.49 & 21.75 \\
\hline 2 & Vertisol & 4.86 & 3.42 & 0.16 & 11.73 & 10.11 \\
\hline 3 & sandy soil & 5.30 & 2.93 & 0.14 & 19.68 & $>40$ \\
\hline 4 & Sandy soil & 6.04 & 5.12 & 0.18 & $>40$ & 19.79 \\
\hline \multicolumn{7}{|c|}{ Zlatokop } \\
\hline 5 & Vertisol & 5.36 & 8.89 & 0.30 & 38.14 & 15.14 \\
\hline 6 & Vertisol & 5.27 & 2.41 & 0.11 & 19.74 & $>40$ \\
\hline
\end{tabular}




\begin{tabular}{|c|c|c|c|c|c|c|}
\hline Soil sample & Soil type & $\mathbf{p H}$ & Humus, $\mathbf{\%}$ & $\begin{array}{c}\mathbf{N}, \\
\mathbf{\%}\end{array}$ & $\begin{array}{c}\mathbf{P}, \\
\mathbf{\%}\end{array}$ & $\begin{array}{c}\mathbf{K}, \\
\mathbf{\%}\end{array}$ \\
\hline 7 & sandy soil & 4.18 & 4.68 & 0.21 & 34.47 & 14.87 \\
\hline 8 & sandy soil & 4.63 & 3.74 & 0.22 & 17 & 21.74 \\
\hline \multicolumn{7}{|c|}{ Ribince } \\
\hline 9 & Vertisol & 5.43 & 8.03 & 0.32 & 30.17 & 30.79 \\
\hline 10 & Vertisol & 5.04 & 5.02 & 0.17 & 19.03 & 23.16 \\
\hline 11 & sandy soil & 4.43 & 3.76 & 0.18 & 12.10 & 30.91 \\
\hline 12 & sandy soil & 5.13 & 2.41 & 0.11 & 16.02 & 11.32 \\
\hline \multicolumn{7}{|c|}{ Kupinince } \\
\hline 3 & Vertisol & 5.67 & 3.32 & 0.13 & 15.43 & 18.01 \\
\hline 14 & Vertisol & 6.64 & 9.07 & 0.41 & $>40$ & $>40$ \\
\hline 15 & sandy soil & 5.38 & 3.51 & 0.16 & 16.54 & 32.18 \\
\hline 16 & sandy soil & 4.69 & 3.84 & 0.12 & 14.78 & 9.97 \\
\hline
\end{tabular}

Source: Author's calculation based on the survey data.

Table 3. The content of various parameters in the examined samples of agricultural crops in the country between October of 2014

\begin{tabular}{|c|c|c|c|c|c|c|}
\hline $\begin{array}{c}\text { Soil } \\
\text { sample }\end{array}$ & Soil type & pH & Humus, \% & $\begin{array}{l}\mathbf{N}, \\
\% \\
\end{array}$ & $\begin{array}{l}\text { P, } \\
\%\end{array}$ & $\begin{array}{l}\mathbf{K}, \\
\% \\
\end{array}$ \\
\hline \multicolumn{7}{|c|}{ Cukovac } \\
\hline 1 & Vertisol & 6 & 3.61 & 0.18 & 10.90 & 32 \\
\hline 2 & Vertisol & 5.78 & 2.62 & 0.13 & 19.18 & 13.33 \\
\hline 3 & sandy soil & 6.05 & 2.54 & 0.13 & 18.94 & 29.87 \\
\hline 4 & sandy soil & 5.82 & 2.16 & 0.11 & 37.97 & 18.54 \\
\hline \multicolumn{7}{|c|}{ Zlatokop } \\
\hline 5 & Vertisol & 4.82 & 3.83 & 0.19 & 30.28 & 17.94 \\
\hline 6 & Vertisol & 5.18 & 2.31 & 0.12 & 18.37 & 38.49 \\
\hline 7 & andy soil & 5.48 & 3.35 & 0.17 & 30.12 & 10.91 \\
\hline 8 & sandy soil & 6.42 & 5.35 & 0.27 & 25.87 & 20.83 \\
\hline \multicolumn{7}{|c|}{ Ribince } \\
\hline 9 & Vertisol & 7.5 & 6.43 & 0.32 & 38.54 & $>40$ \\
\hline 10 & Vertisol & 4.92 & 3.01 & 0.15 & 16.86 & 17.84 \\
\hline 11 & sandy soil & 6.41 & 4.61 & 0.23 & 15.96 & 37.42 \\
\hline 12 & sandy soil & 6.99 & 6.02 & 0.30 & 23.12 & $>40$ \\
\hline \multicolumn{7}{|c|}{ Kupinince } \\
\hline 13 & Vertisol & 4.49 & 7.53 & 0.38 & 12.59 & 10.71 \\
\hline 14 & Vertisol & 4.89 & 3.69 & 0.18 & 35.41 & 34.26 \\
\hline 15 & sandy soil & 4.67 & 4.24 & 0.21 & 20.15 & 28.77 \\
\hline 16 & sandy soil & 5.58 & 3.27 & 0.16 & 18.43 & 21.67 \\
\hline
\end{tabular}

Source: Author's calculation based on the survey data.

If we compare the results from Tables 1 and 2 it can be seen that there are no major changes before and immediately after the flood. This means that the land retains its own quality. 
After a certain period, the land, which was flooded, was treated with fertilizers means and the results obtained in Table 3 show the quality of the soil after the application of fertilizers. The Malawi fertilizer subsidy program is a rare example of that has led to substantial changes in farm use of fertilizers and the rapid shift of the soil from food deficit to food exporter (Dorward and Chirwa, 2011).

Based on the results obtained at three periods of observation it can be said that there is a relatively high level of sustainability parameters of soil chemical quality in the South Morava valley, due to the flood occurred in May 2014. Examined soils in the valley of the South Morava river is characterized by a slightly weaker grain size composition on the north side of the study area (samples 2, 3, 4, 6). It represented that soil texture is sandy to sandy loam, while on the south side (samples $8,9,12,13,15$ ) represented the clay loam soil samples texture. Considering $\mathrm{pH}$ of the samples are is in the range from acidic (samples 9 and 12) to slightly acidic (samples no. 1, 2, 3, 4, 5, 6, 7, 8, 10,11, 13, 14,15 , and 16). It is believed that these soil samples appropriate acidity and that such soil are suitable for crop farming and orchardings. Studied soils are not calcarious. The humus content in all samples is high except in samples 2, 3, 4 and 6 where it records low values that do not favor the plants. Higher values indicate that the humus soil is favouras for all crops. The quantity and quality of humus in the soil is constantly being renewed, or the amount of new topsoil to replace the old and thus maintains a certain level of humus in the soil, which is intended for planting of some crops. This balance is of great importance for the creation and maintenance of soil fertility. (Altieri, et al. 1995). In this paper, humus content in the examined samples meet the expected value of around 3. The obtained values of humus content in the analyzed samples even moving through third. Changes in the chemical indicators of soil quality (KP N) does not depend only on the type of soil, and whether or not there was flooding, but also depend on the depth, as well as the location, and sampling. How would later plant absorb the amount of these elements in the soil depends on how the plants are arranged and which species are concerned. For example, in the land where he planted a pear, the percentage and the amount of $\mathrm{N}$ and $\mathrm{P}$ were higher in soil layer $0-20 \mathrm{~cm}$ were higher than those in the 20-40 cm soil layers and 40-60, while the percentage of $\mathrm{K}$ at a depth of 40-60 cm soil layer was higher than in soil layers 0-20 cm and 20-40. (Xu et al., .2013).

Total nitrogen content is at the level of provision of good, which is a consequence of adequate and appropriate application of fertilizers. Another indication of the input samples of fertilizers in the soil's balance of carbon and nitrogen, which indicates the extent of its availability to the plants. It is an important indicator, or an indicator of the speed of transformation of organic residues, the quality of humic. The nitrogen content in the analyzed samples of the soil ranges from 0.1 to $0.30 \%$ (i.e. from $0.11 \%$ to $0.34 \%$ ), which is the expected value for this area. The potassium content ranged from low values (samples 5 and 6) through the medium (samples 2, 3, 4, 7, 10, 13, 14 and 15), up to high values (samples $1,8,16$ ), as well as excessively high values (samples $9,11,12$,). Soil samples with high potassium content shouldn't be fertilized to avoid saturation that could impact yield and yield quality. Phosphorous (P) is very low in 
the samples 5, 14, in samples No. 1, 2, 3, 4, 6, 7, 10, 13, 15 and 16, the phosphorus content is moderately high, while in samples 8, 9, 11 and 12 showed high quantity of this element.

Figure 2. The contents of soil $\mathrm{pH}$ (left), and humus values in\% (right) before, immediately after and after the floods
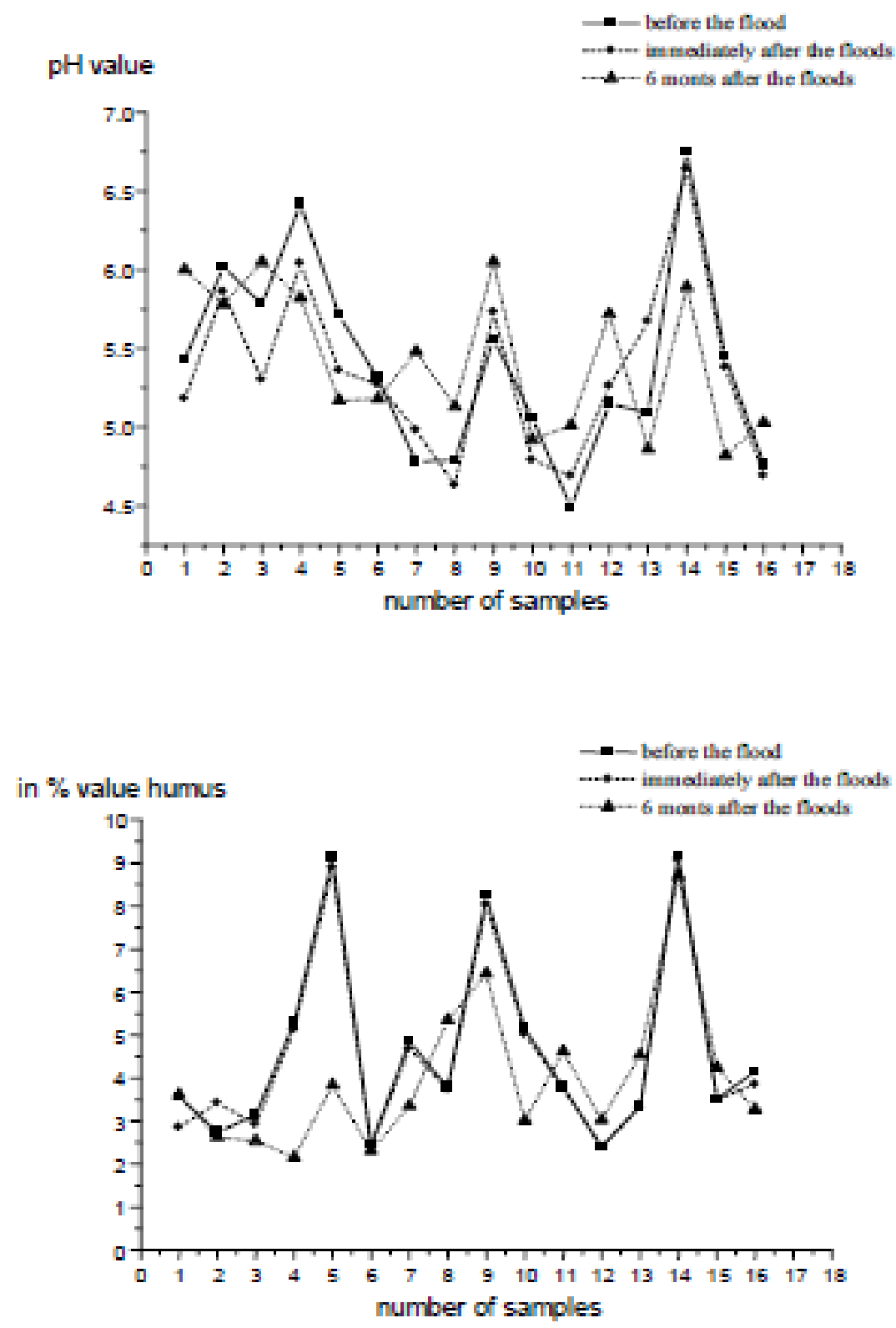

Source: Author's calculation based on the survey data. 
Figure 3. Content of nitrogen values in \% (left) and phosphorous values in\% (right) before, immediately after and after the floods
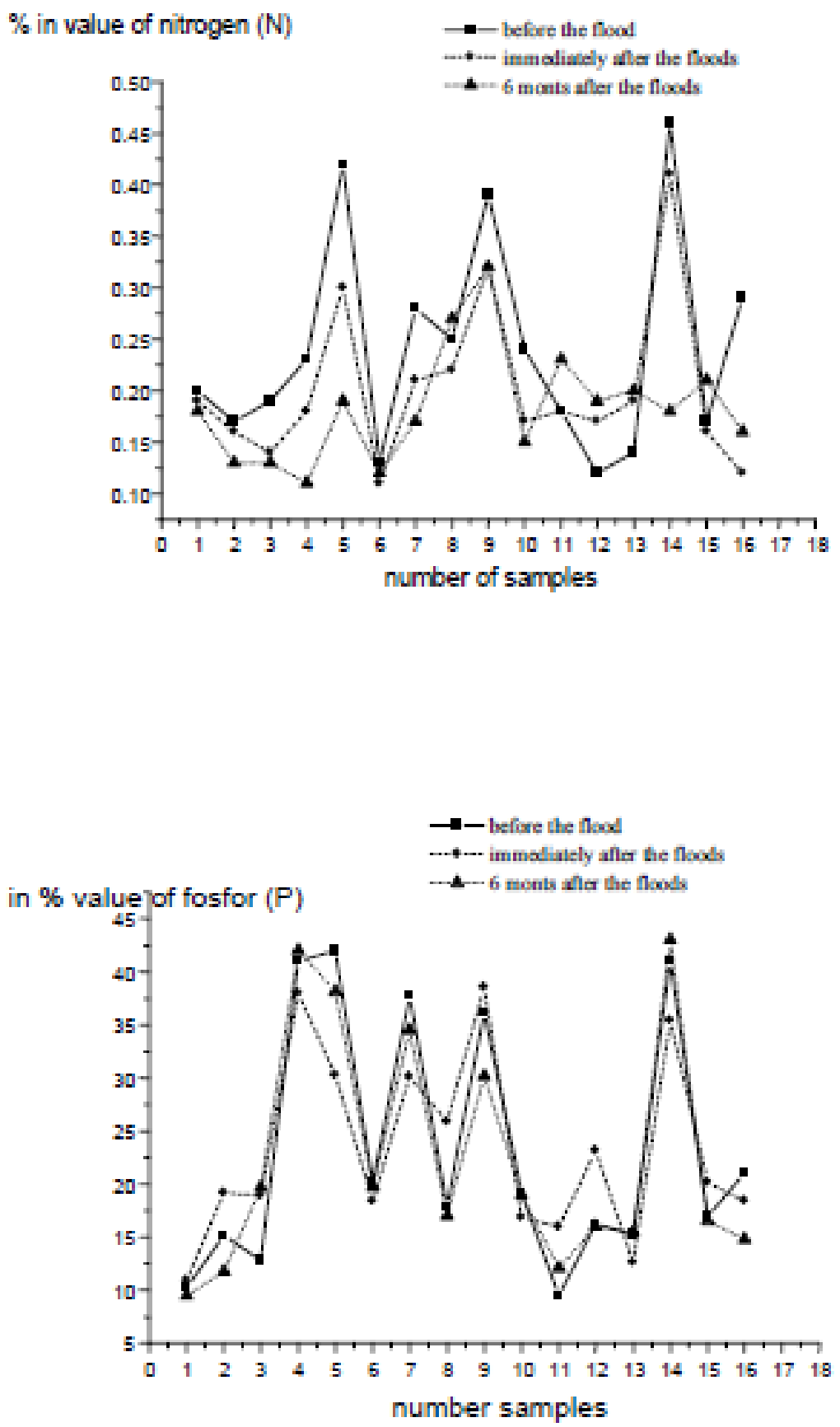

Source: Author's calculation based on the survey data. 
Figure 4. The content of kalijum values in $\%$ before, immediately after and after the floods

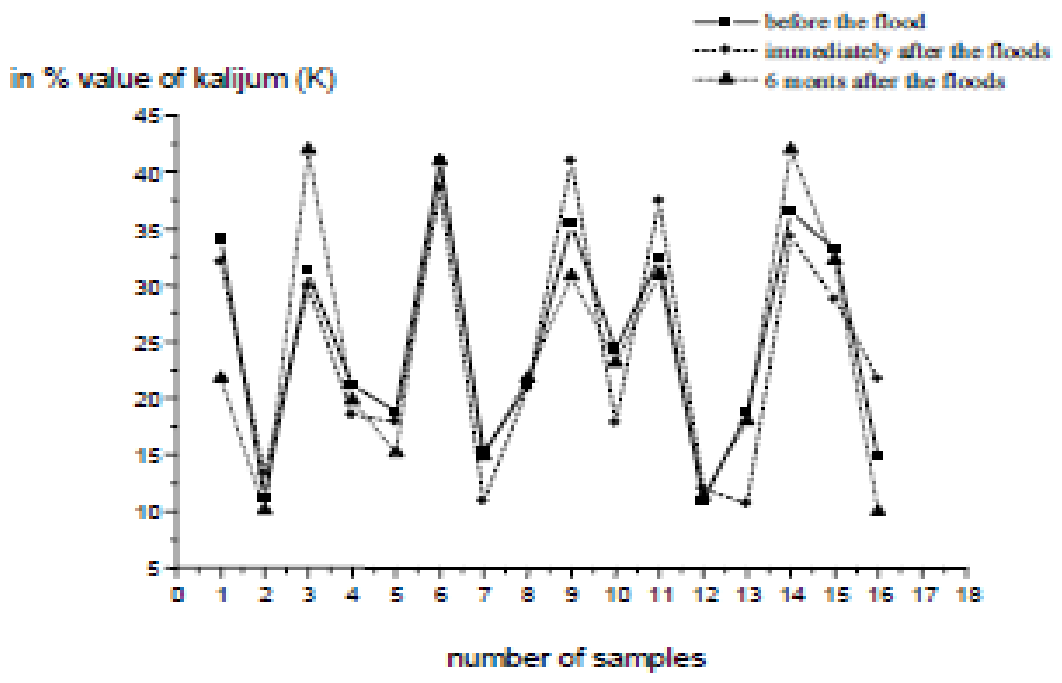

Source: Author's calculation based on the survey data.

In the Figure 2 (Figure 2 left ) it can be seen that the $\mathrm{pH}$ value of the soil after the flood, changed the value greatly in comparison with values obtained before flooding. It can be concluded that the soil is more acidic, but not so much that could pardize its quality. The graphs in Figure 3 right, and 3 are approximately the same. This means that the sustainability of the nutrient quality of the soils along the valley of the River South Morava not endanger by the floods where water is retained more than 20 days.

On the basis of the results of the soil samples, it can be concluded that chemical property of the soil's are satisfactory for growing crops, almost at all locations from which samples were taken before and after a flood. Favorable results are influencedby favorable environmental factors, as well as a good geographical position.. The influence of climatic factors in the future will significantly affect the cultivation of crops and will be of fundamental importance for the survival of people (Campbell, 2012).

\section{Conclusion}

This paperis research about the sustainability of soil quality in corelation to flooding. Various soil samples from different locations in the South Morava River valley where examined. Samples were taken after harvest in the period before, immediately after the flood and the 6 months after the flood. The test results that were obtained showed that the samples examined in the regionsoil of satisfactory quality for growing crops, including even land that was flooded. The soil type is sandy and clays as well assoil type shifts, the results are good. The results showed that the samples of soil mainly with $\mathrm{pH}$ around 7, that are acidic; that some samples of soildo not need extra fertilization because they are rich in phosphorus and potassium (phosphorus and potassium have values greater than 40). The results showed that soil is rich in humus because in all 
samples the value of humus is around 3-3.5.

On the basis of the research it can be concluded that the growing of crops and other crops are correct and viable strategyof development of the South Moravavalley and the entire region of South Serbia. The analyzed region in the long-term plans can be considered good for farming because the land has a certain quality that is sustainable even in conditions of extreme floods. Due to long-term sustainability, agriculture investment in this region is fisible.

\section{Literature}

1. Altieri, M.A. (1995): Agroecology: The science of sustainable agriculture, 2nd edition, Westview Press., 446, 1-85339-295-2.

2. Altieri, M. Nicholls, C., (2005): Berkeley Agroecology and the Search for a Truly Sustainable Agriculture, United Nations Environment Programme Environmental Training Network for Latin America and the Caribbean Boulevard de los Virreyes 155, University of CaliforniaColonia Lomas de Virreyes Mexico D.F., Mexico.

3. Campbell, B., (2012): Open-pollinated seed exchange: renewed Ozark tradition asagricultural biodiversity conservation, Journal of Sustainable Agriculture, Vol. 36, pp 500-522.

4. Conway, G. R., Waage, J., (2010): Science and Innovation for Development, UKCDS, London.

5. Godfray, C., Beddington, J. R., Crute, I. R., Haddad, L., D., Muir, J. F., Pretty, J., Robinson, S., Thomas, S.M., Toulmin, C., (2010): Food security: the challenge offeeding 9 billion people, Science Vol. 327, pp 812-818.

6. Dorward, A., Chirwa, E., (2011): The Malawi Agricultural Input Subsidy Programme: 2005-06 to 2008-09', International Journal of Agricultural Sustainability Vol. 9, No. 1, pp 232-247.

7. Ling-fei Hu, Peng Zhou, Qing-fang Han, Zhi-hui Li, Bao-ping Yang, Jun-feng Nie, (2013): Spatial Distribution of Soil Organic Matter and Nutrients in the Pear Orchard Under Clean and Sod Cultivation Models, Journal of Integrative Agriculture, Volume 12, Issue 2, Pages 344-351.

8. Krnacova, Z., Hresko, J., Kanka R., Boltiziar, M., (2013): The evalution of ecologicalfactors affecting environmental functions of the soils in area of traditionalagrarian structures. Ekol. Bratislava Vol. 32, No. 2, pp 248-261.

9. Mcintyre, B., et al., (2011): The best-laid plans: climate change and food security. Climate and development, Vol. 3, pp 281-284.

10. Spulerova, J., (2008): Succession changes in extensively used agricultural soil,. Ecosystems and Environment, Vol. 27, No. 1, pp 54-64, Bratislava,.

11. Pretty, J.,(2008): Agricultural sustainability: concepts, principles and evidence, Philosophical Transactionsof the Royal Society of London, Series B 363(1491), pp 447-466

12. Stevanovic, B., Jankovim,M., (2001): Ecology of plants with basics of plant physiology. NNK International, Belgrade, pp 514

13. Stevovic, S., (2010): Environmental impact on morphological and anatomical structure of Tansy, African Journal of Biotehnology, Vol. 9, No. 16, pp 2413-2421. 
14. Stevovic S., Calic-Dragosavac D., (2010): Environmental study of heavy metal influence on soil and Tansy (Tanacetum vulgare L.), African Journal of Biotehnology Vol. 9, No. 16, pp 2392-400.

15. Stevovic S., Mikovilovic-Surcinski, V., Calic-Dragosavac, D.,(2010): Enviromental impact of site location on marco-and microelements in Tansy, African Journal of Biotehnology Vol. 9, No. 16, pp 2408-12.

16. Stevovic, S., Mikovilovic - Surcinski V., Calic-Dragosavac, D., (2009): Environmental adaptibility of tansy (Tanacetum vulgare L.,)'African Journal of Biotehnology Vol. 8, No. 22, pp 2025-2032

17. Stevovic S, Dervnja, N., Calic-Dragosavac, D., (2013): Environmental impact quantification and correlation between site location and contents and structure of Tansy, African Journal of Biotehnology Vol. 10, No. 26, pp 75-83.

18. Stevovic, S., et al., (2011): Correlation Between Environment and Essential Oil Production in Medical Plants, Advances in Environmental Biology, Vol. 5, No. 2, pp 465-68.

\title{
ODRŽIVOST KVALITETA ZEMLJIŠTA U DOLINI REKE JUŽNA MORAVA I KORELACIJA SA POPLAVAMA
}

\author{
Jelena Markovic ${ }^{4}$, Svetlana Stevovic ${ }^{5}$
}

\section{Rezime}

Zemljište kao glavni faktor, igra veoma važnu ulogu u proizvodnji raznih ratarskih kultura, voća i povrća. Njegova uloga se ogleda u plodnosti i produktivnosti. Plodnost zemljišta obuhvata sadržaj dostupanih hranljivih materija, kao što su, pH, N, K, P $i$ humusa. U radu su prikazani rezultati istraživanja promena u kvalitetu zemljišta u dolini Južne Morave, u korelaciji sa poplavama. Istraživanja koja su sprovedena, pokazala su da su parametri pH, N, K, P, u funkciji vremena. Eksperiment je sproveden pre dve godine, odmah posle potopa i šest meseci nakon poplava, koje su se dogodile u maju 2014. godine u regionu južne Srbije. Metode koje su korišćene su: kolorimetrijske, fotometrijske, potenciometrijske i spektrometrijske. Rezultati pokazuju visok stepen održivosti kvaliteta zemljišta namenjenog za gajenje ratarskih kultura. Zaključakje da se zemljište relativno brzo regeneriše nakon poplava.

Ključne reči: Južna Morava, zemljište, kalijum, fosfor, humusa, poplave.

4 Dr Jelena Markovic, profesor strukovnih studija, Visoka škola primeljenih strukovnih studija, Vranje, Filipa Filipovića 20, Vranje, Srbia, Ovo istraživanje podržalo je Ministarstvo prosvete, nauke i tehnološkog razvoja Srbije, broj EE18031 и ТР35030. Phone: +381 652040022, E-mail: gogaijeka94@gmail.com.

5 Dr Svetlana Stevovic, redovni profesor, Univerzitet Union Nikola Tesla, Fakultet za ekologiju i zaštitu životne sredine, Beograd, Cara Dusana 62-64, Beograd, Srbia, Phone: +381 638882541, E-mail: svetlanas123@gmail.com 
ECONOMICS OF

AGRICULTURE

\section{CONTENT}

1. Adriana Radosavac, Desimir Knežević

ECONOMIC IMPORTANCE OF USE

OF PESTICIDES IN WHEAT PRODUCTION . . . . . . . . . . . 1323

2. Berhe Gebregewergs, Muuz Hadush

DOES CLIMATE CHANGE AFFECT PRICE OF VEGETABLES:

EVIDENCE FROM TIGRAI, NORTHERN MOST ETHIOPIA. . . . .1335

3. Grujica Vico, Aleksandra Govedarica-Lučić, Zoran Rajić, Radomir Bodiroga, Ivan Mičić, Silvija Zec Sambol, Marija Mičić

MULTI ATTRIBUTE ASSESSMENT APPROACH

IN VEGETABLE PRODUCTION . . . . . . . . . . . . . . 1355

4. Igor Trandafilović, Vesna Conić, Aleksandra Blagojević

IMPACT OF DEMOGRAPHIC FACTORS ON

ENVIRONMENTALLY CONSCIOUS PURCHASE BEHAVIOUR. . .1365

5. Imre Milán Harcsa

STUDY ON THE POTENTIAL OF SUBCONTRACT

PALINKA DISTILLATION . . . . . . . . . . . . . . 1379

6. Jelena Andrašić, Vera Mirović, Nada Milenković, Branimir Kalaš, Miloš Pjanić

IMPACT OF TAKEOVER PROCESS ON EMPLOYEES -

EVIDENCE FROM FOOD, RETAIL AND FINANCIAL SECTOR . . .1393

7. Jelena Birovljev, Danilo Đokić, Bojan Matkovski, Žana Kleut

ECONOMIC PERFORMANCES OF AGRICULTURE

OF CEFTA AND FORMER CEFTA COUNTRIES . . . . . . . . . . 1413

8. Jelena Marković, Svetlana Stevović

SUSTAINABILITY OF CHEMICAL SOIL QUALITY

IN SOUTHERN MORAVA RIVER VALLEY

IN CORELLATION WITH THE FLOODING $\ldots \ldots \ldots \ldots \ldots$ 
9. Mile Peševski, Zoran Milovančević

THE CHANGES IN THE USAGE OF AGRICULTURAL LAND

IN EASTERN REGION OF REPUBLIC OF MACEDONIA

BETWEEN $1991-2030 \ldots \ldots$. . . . . . . . . . . . . . . . . . . . . . .

10. Odjuvwuederhie Emmanuel Inoni, 'Oraye Dicta Ogisi, Felix Odemero Achoja

PROFITABILITY AND TECHNICAL EFFICIENCY IN HOMESTEAD

CATFISH PRODUCTION IN DELTA STATE, NIGERIA . . . . . . . 1449

11. Olja Munitlak - Ivanović, Jovan Zubović, Petar Mitić

RELATIONSHIP BETWEEN SUSTAINABLE DEVELOPMENT AND

GREEN ECONOMY - EMPHASIS ON GREEN FINANCE

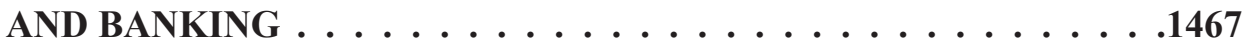

12. Petar Munćan, Dragica Božić

FARM SIZE AS A FACTOR OF EMLOYMENT AND INCOME

OF MEMBERS OF FAMILY FARMS . . . . . . . . . . . . . 1483

13. Rade Popović, Mira Kovljenić

EFFICIENCY OF WHEAT PRODUCTION ON FARMS

IN THE REPUBLIC OF SERBIA . . . . . . . . . . . . . . . . . . . . . . . . .

14. Radovan Damnjanović, Snežana Krstić, Milena Knežević, Svetislav Stanković,

Dejan Jeremić

THE DISCRIMINANT ANALYSIS APPLIED TO THE

DIFFERENTIATION OF SOIL TYPES . . . . . . . . . . . . 1513

15. Slavica Otović, Dunja Demirović, Kristina Košić, Aleksandra Vujko

FOSTERING ENTERPRENUERSHIP AT HIGH SCHOOLS:

A CASE OF RURAL AREAS IN VOJVODINA (SERBIA) . . . . . . .1523

16. Vladimir Ilić, Ivan Bauer, Anastazija Tanja Đelić, Aleksandar Nešković

INSTITUTIONAL SUPPORT FOR STRENGTHENING

ENTREPRENEURSHIP IN AGRICULTURAL PRODUCTION

OF THE REPUBLIC OF SERBIA . . . . . . . . . . . . . . . . . . . . . . . .

17. Boro Krstić, Zorica Vasiljević, Miroslav Nedeljković

INSURANCE CONTRACT AS THE BASIS FOR THE SAFETY OF

AGRICULTURAL PRODUCERS IN THE REPUBLIC OF SRPSKA • . 1555

18. Dejan Sekulić, Aleksandar Petrović, Vladimir Dimitrijević

WHO ARE WINE TOURISTS? AN EMPIRICAL INVESTIGATION

OF SEGMENTS IN SERBIAN WINE TOURISM . . . . . . . . . . . . . 
19. Milan Beslać, Ćorić Goran

FINANCIAL AND PRODUCTION ASPECTS OF GENETICALLY MODIFIED ORGANISMS $\ldots \ldots \ldots \ldots \ldots \ldots \ldots \ldots \ldots$

20. Mlađan Maksimović, Darjan Karabašević, Miodrag Brzaković, Pavle Brzaković THE EFFECTS RESULTING FROM THE APPLICATION OF THE CONCEPT OF THE SUSTAINABLE DEVELOPMENT OF RURAL TOURISM ON STARA PLANINA . . . . . . . . . . . . . . . .1595

21. Vesna Popović, Predrag Vuković, Milivoje Ćosić FOOD SAFETY AND QUALITY POLICY IN THE REPUBLIC OF SERBIA . . . . . . . . . . . . . . . . 1607

22. Radovan Pejanović, Danica Glavaš-Trbić, Mirela Tomaš-Simin PROBLEMS OF AGRICULTURAL AND RURAL DEVELOPMENT IN SERBIA AND NECESSITY OF NEW AGRICULTURAL POLICY . . . .1619

23. Saša Marković, Slavoljub Vujović, Aleksandar Damnjanović MARKETING AND HIGHER EDUCATION CONDITION IN SERBIA . . . . . . . . . . . . . . . . 1635

24. Semir Vehapi, Marina Milanović THE EFFECT OF MARKET ORIENTATION ON BUSINESS PERFORMANCE OF SERBIAN ORGANIC PRODUCERS . . . . . 1651

25. Suad Bećirović, Šemsudin Plojović, Enis Ujkanović, Senadin Plojović CHALLENGES AT STARTING AN AGRIBUSINESS IN THE HILLY MOUNTAINOUS REGIONS OF SOUTHWEST SERBIA . . . . . . . .1669

26. Vladimir Zakić, Vlado Kovačević, Jelena Damnjanović SIGNIFICANCE OF FINACIAL LITERACY FOR THE AGRICULTURAL HOLDINGS IN SERBIA . . . . . . . . . . 1687

27. Željko Bjelajac, Marijana Dukić Mijatović, Željko Vojinović PROTECTION OF LAND IN THE REPUBLIC OF SERBIA AND ECOLOGICAL SECURITY WITH REGARD TO STRATEGIC AND LEGAL FRAMEWORKS . . . . . . . . . .1703 